\title{
ROLE OF REPLACEMENT IN THE GENESIS OF ANORTHOSITE IN THE BOEHLS BUTTE AREA, IDAHO
}

\begin{abstract}
ANNA HIETANEN
HIETANEN, ANNA, 1986: Role of replacement in the genesis of anorthosite in the Boehls Butte area, Idaho. Bull. Geol. Soc. Finland 58, Part 1, 71-79.

In the Boehls Butte area, Idaho, three large and numerous small lenses of layered to massive anorthosite consisting of two, and locally three, types of plagioclase and minor hornblende and micas occur in aluminum silicate-rich garnet mica schist. In most of this anorthosite, andesine megacrysts with bytownite inclusions are embedded in a fine-grained groundmass of bytownite or anorthite. In places labradorite occurs instead of andesine. Some labradorite laths show Carlsbad twinning and rims of andesine around anorthite inclusions. Along the contacts, lenses of fine-grained bytownite anorthosite with some hornblende or garnet and quartz are common. These lenses could represent calcic parent rocks that were changed to two-plagioclase rocks by partial replacement of bytownite by andesine.
\end{abstract}

Key words: anorthosite, andesine-bytownite rocks, Al-silicates, triple point.

Anna Hietanen: U.S. Geological Survey, Branch of Western Regional Geology 345 Middlefield Rd., MS 75, Menlo Park, CA 94025.

\section{Introduction}

Three large and several small lens-shaped bodies of layered, foliated, or massive two- to threeplagioclase anorthosite with complicated textural relationships occur in the aluminum silicate-rich garnet-mica schist of the Boehls Butte Formation. This formation, now considered to be Proterozoic basement beneath the Belt Supergroup, is exposed in an uplifted block northwest of the Idaho batholith (Figs. 1 and 2; Hietanen 1963, 1969a, 1984). The uplifted block, about $460 \mathrm{~km}^{2}$ in area, is separated by faults from the overlying metasedimentary rocks of the Proterozoic Belt Supergroup (Fig. 2). The metamorphic grade of the rocks of the overlying Belt increases, toward the Idaho batholith, from biotite grade near the St. Joe River to sillimanite-muscovite grade next to the batholith, $50 \mathrm{~km}$ to the south. In the uplifted block (the Boehls Butte area) all three aluminum silicates - kyanite, andalusite, and sillimanite - occur together in garnet-mica schist that locally contains cordierite or staurolite and is rich in plagioclase near the anorthosite bodies.

Since my initial work (Hietanen, 1963, 1969a) which discussed the possibilities of metamorphicmetasomatic and modified igneous origin of these unusual anorthosite masses, two detailed unpublished reports on various aspects of the genesis of these rocks have been written. Nord (1973) made an extensive electron microprobe 


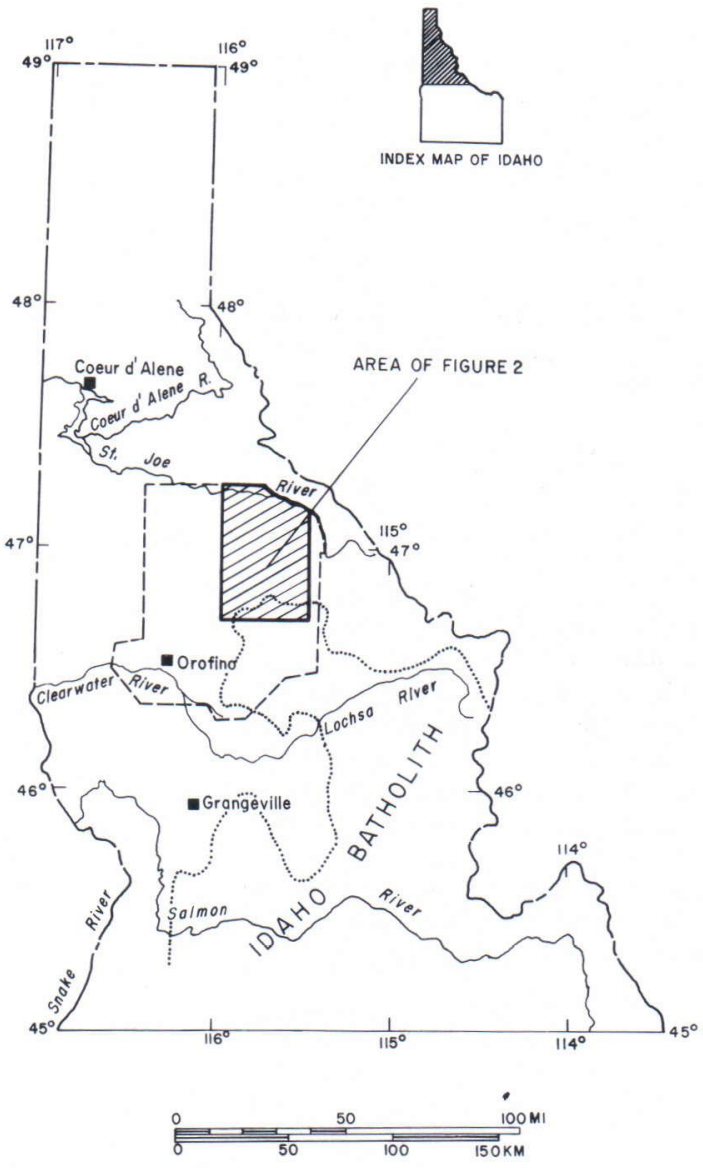

Fig. 1. Index map of northern Idaho. Outline of the area studied shown by dashed line. Outline of Idaho batholith shown by dotted line.

study of the coexisting plagioclases and agreed with me that the andesine was younger and had partially replaced the calcic plagioclase. Labradorite rather than andesine occurs locally in the northern part of the area; some of it shows Carlsbad and complex twinnings common in plagioclase crystallized in a liquid environment. Juras (1974) concentrated on the study of structures in the field; he suggested 10 episodes of deformation in the anorthosite and assumed that a shear differentiation and exsolution had produced andesine and bytownite from an igneous labradorite rock.

\section{Boehls Butte Formation}

The rocks of the uplifted block were named the Boehls Butte Formation by Hietanen (1969a). The lowest unit of this formation (Table 1), the aluminum silicate-rich garnet-staurolite-mica schist underlies the two northern anorthosite bodies. The schist, which is exposed west and south of the northernmost large anorthosite body, dips under it (Fig. 2), is enriched in plagioclase, and includes several small lenses of layered anorthosite with gradational contacts. A thin unit of aluminum silicate-rich schist that contains cordierite and corundum and is locally enriched in plagioclase overlies the anorthosite bodies and is in turn overlain by a quartzite unit and an upper schist unit. Lenses and layers of hornblende schist, amphibolite, and garnet amphibolite occur in all units.

Most of the quartzite is light gray and thin bedded with muscovite and biotite laminae. Interbedded are layers of coarse-grained white granular quartzite, very light gray micaceous quartzite, and calc-silicate rocks. The thickness of this unit decreases to the south; only thin layers of quartzite are interbedded with the schist that overlies the southernmost large anorthosite body. The calc-silicate rocks commonly consist of a combination of three to five of the following minerals: diopside, tremolite, hornblende, anorthite, andesine, grossularite, scapolite, quartz, calcite, and zoisite. Rutile, sphene, hematite, and graphite occur as accessory minerals.

The upper schist unit exposed on Smith Ridge and in the eastern part of the uplifted block is coarse-grained garnet-biotite-muscovite schist, locally rich in kyanite. The upper part of this unit exposed on Smith Ridge (Fig. 2) between the middle and southern anorthosite bodies is distinctly laminated; it contains thin layers of plagioclase $\left(\mathrm{An}_{25-35}\right)$, quartz, and some small biotite flakes separated by biotite-muscovite laminae. In the lower part of the unit, overlying the southernmost anorthosite body layers of cordierite-kyanite-andalusite-sillimanite-biotite 


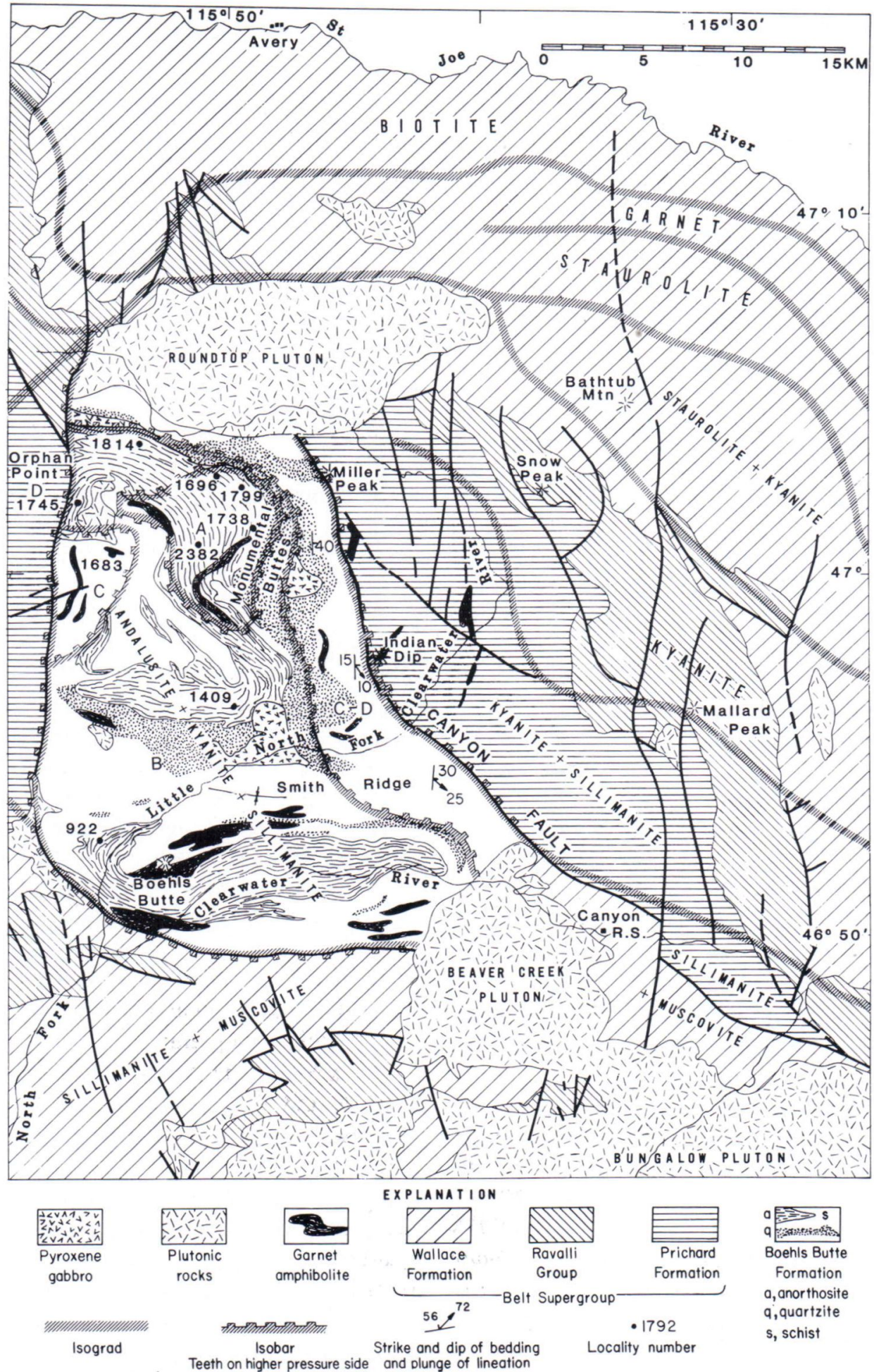

Fig. 2. Geologic sketch map of the Boehls Butte area and vicinity. Zone A, Kyanite partly altered to andalusite. Cordierite, staurolite, and garnet. Zone B, Andalusite, kyanite, and sillimanite, together. Cordierite, staurolite, and garnet. Zone C, Sillimanite, staurolite, and garnet. Kyanite partly altered to sillimanite. Zone D, Kyanite and garnet; sillimanite in places (see details in Hietanen 1969a). 
Table 1. Generalized section of the Boehls Butte formation.

\begin{tabular}{|c|c|c|}
\hline Unit & Rock Type & $\begin{array}{l}\text { Thickness } \\
\text { in meters }\end{array}$ \\
\hline Upper schist & $\begin{array}{l}\text { Garnet-biotite-muscovite schist in part laminated with thin biotite-plagioclase-quartz } \\
\text { layers. Locally rich in kyanite. }\end{array}$ & 800 \\
\hline Quartzite & $\begin{array}{l}\text { Thin-bedded fine-grained biotite quartzite and coarse-grained white to very light gray } \\
\text { foliated quartzite. Interbedded locally are calc-silicate rocks, phlogopite- or biotite- } \\
\text { plagioclase rocks, and kyanite-andalusite-silimanite schist containing plagioclase. }\end{array}$ & $\begin{array}{l}300- \\
800\end{array}$ \\
\hline $\begin{array}{l}\text { Feldspathized } \\
\text { schist }\end{array}$ & $\begin{array}{l}\text { Coarse-grained kyanite-andalusite-sillimanite-garnet-mica schist containing plagioclase } \\
\left(\mathrm{An}_{25-45)} \text { and cordierite or staurolite. }\right.\end{array}$ & $0-200$ \\
\hline Anorthosite & $\begin{array}{l}\text { Anorthosite is a layered and foliated or massive bimodal or trimodal plagioclase } \\
\text { rock. In layered rock, white to light-gray layers consisting of large oval grains of } \\
\text { andesine } \mathrm{An}_{40-45} \text { with inclusions and groundmass of } \mathrm{An}_{80-95} \text { are interbedded with } \\
\text { thin layers rich in hornblende or in aluminum silicates, biotite and muscovite. } \\
\text { Massive parts are coarse-grained andesine-bytownite rocks or labradorite with } \\
\text { anorthite-andesine inclusions. Layers of bytownite-anorthite rock with garnet and } \\
\text { quartz or with hornblende occur along the contacts. }\end{array}$ & $\begin{array}{l}800- \\
2500\end{array}$ \\
\hline Lower schist & $\begin{array}{l}\text { Kyanite-andalusite-sillimanite-biotite-muscovite schist with local garnet, cordierite, } \\
\text { and staurolite. Contains plagioclase } \mathrm{An}_{25-45} \text { and lenses of coarse-grained andesine } \\
\text { and fine-grained bytownite or labradorite anorthosite. }\end{array}$ & $\begin{array}{l}400- \\
600\end{array}$ \\
\hline
\end{tabular}

gneiss with some quartz, muscovite, and corundum (Hietanen 1956) are interbedded with garnet-mica schist. In the northern part of the area, near Monumental Buttes (east of locs. 1738, 1799, Fig. 2), the amount of sillimanite is less and cordierite either occurs as large aggregates or as reaction seams between the kyanite and biotite or between the kyanite and anthophyllite. Corundum, rutile, and apatite are common accessory minerals. Nord (1973) calculated the slopes of cordierite-producing reactions and estimated the minimum pressure to be $5 \mathrm{~kb}$ and the minimum temperature to be $580^{\circ} \mathrm{C}$ for the crystallization of the kyanite-phlogopite-quartz assemblage in these rocks. Schreyer and Seifert (1969) have discussed the reaction talc $+\mathrm{Al}$ silicate $=$ cordierite + corundum $+\mathrm{H}_{2} \mathrm{O}$ and suggested that corundum forms stably with cordierite. Seifert (1973) proved this experimentally, and he determined temperatures of $615^{\circ} \mathrm{C}$ for the formation of $\mathrm{Mg}$-cordierite + corundum at a pressure of $5 \mathrm{~kb}$ in the reaction chlorite + Al-silicate $=$ cordierite + corundum $+\mathrm{H}_{2} \mathrm{O}$.

Using various geologic thermometers and the load of eroded overburden, the temperature and pressure of the triple point of kyanite, andalusite, and sillimanite in the Boehls Butte area were estimated to be $580^{\circ} \mathrm{C}$ and $5 \mathrm{~kb}$ (Hietanen 1969a). These values lie well within the range determined experimentally by Richardson, Gilbert and Bell (1969), Althaus (1967), and Newton (1966). The occurrence of cordierite or staurolite with the aluminum silicates provides information about the relative pressures of recrystallization in various parts of the uplifted block; the isobars shown in figure 2 are based on that information.

The schist near the anorthosite is coarsegrained and is rich in andesine $\left(\mathrm{An}_{45}\right)$ which occurs as individual grains, groups of grains, and small masses. The anorthite content and the number and size of the plagioclase grains all decrease within 20 to $500 \mathrm{~m}$ from the contact, and the feldspathized schist changes to garnet-mica schist that is locally rich in aluminum silicates. As the amount of plagioclase decreases, the quartz increases until it makes up 10-40 percent of the aluminum silicate-brearing garnet-mica schist.

Instead of cordierite, garnet and staurolite occur with all three aluminum silicates in the 
schist below the anorthosite. Quartz, plagioclase, biotite, muscovite, chlorite, and corundum are common additional constituents of all the schist. The percentage of quartz is highly variable, ranging from negligible to more than 50 percent. The biotite is a brown variety with a $\mathrm{MgO} / \mathrm{FeO}$ ratio of about $1: 5$, whereas in the cordieriterich rocks it is a greenish $\mathrm{Mg}$-biotite with a $\mathrm{MgO} / \mathrm{FeO}$ ratio of about $3: 1$ (Hietanen $1969 \mathrm{~b}$ ). The garnet in the staurolite schist is almandine with 5 percent $\mathrm{CaO}$.

\section{The anorthosite}

The three large conformable sheet-like anorthosite bodies - 1/2 to $2 \mathrm{~km}$ thick - are exposed on crests of anticlines: the northern and middle body on the nose of a double-crested anticline and the southern body in the anticlinal valley of the North Fork of the Clearwater River (Fig. 2). This structure and the rock units exposed above the anorthosite suggest that all three large bodies occur in the same stratigraphic horizon in the Boehls Butte Formation (Table 1).

The layered anorthosite, which makes up most of the two large southern masses and small bodies, consists of white to very light bluish gray layers $(5-50 \mathrm{~cm}$ thick) of two-plagioclase rock and thin $(2-5 \mathrm{~cm}$ thick) dark-colored layers that are rich in hornblende or in biotite, muscovite, and aluminum silicates. In the plagioclase layers, large (5 to $10 \mathrm{~mm}$ long) oval andesine megacrysts are embedded in a fine-grained groundmass of calcic plagioclase that consists of bytownite and/or anorthite. The andesine megacrysts include numerous small grains of similar calcic plagioclase (Fig. 3). The compositions of the two plagioclases, determined optically by Hietanen (1963, 1969a) and by electron microprobe by Nord (1973), generally are in the range $\mathrm{An}_{40-45}$ for andesine and $\mathrm{An}_{80-97}$ for bytownite-anorthite. The bytownite-anorthite inclusions in andesine are lamellar or show irregular outlines but crystallographic parallel orientation with the host andesine. The two plagioclases occur also
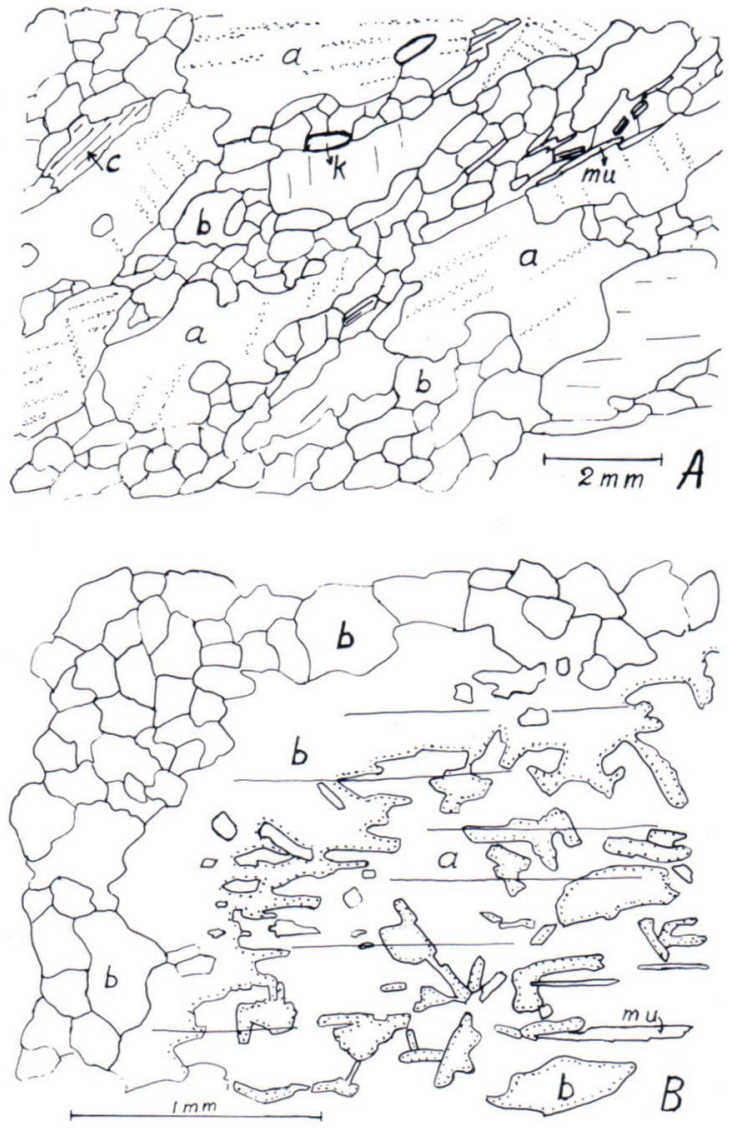

Fig. 3. Camera lucida drawings of anorthosite in the Boehls Butte Formation. A, Foliated border zone (loc. 1738, Fig. 2). Large plagioclase grains (a) are andesine and small interstitial grains (b) are bytownite. Muscovite (mu), chlorite (c), and kyanite (k) occur as minor constituents. B, Lower right corner shows a part of an andesine megacryst (a) with inclusions and rim of bytownite (b) in a groundmass of small grains of bytownite on the left. The rim and the inclusions are in crystallographic continuity. The grains in the groundmass are at random; mu, muscovite; $1 \mathrm{~km}$ southeast of location 2382 in figure 2.

in the dark layers, bytownite-anorthite as aggregates of small polygonal grains and andesine as large twinned grains. In places, two kinds of andesine and bytownite make up the plagioclase layer in the anorthosite. In these layers most of the andesine is in medium-size ( 3 to $5 \mathrm{~mm}$ long), slightly elongate and twinned grains without inclusions (Fig. 3A) or, rarely, 
with only a few inclusions that occur in a portion of a grain. Some large round andesine grains, however, contain numerous bytownite inclusions. Interstitial small grains of bytownite have a highly irregular distribution in this rock. The clear andesine grains without inclusions are similar to the andesine in the feldspathized country rock.

All three aluminum silicates - kyanite, andalusite, and sillimanite - are common in biotite and muscovite-bearing layers in the anorthosite. In the southernmost body, kyanite occurs with hornblende and biotite in many dark layers (Hietanen 1963, 1969a). Thick layers and lenses of white plagioclase rock in this body are massive and contain less bytownite than does the common layered variety. Locally, aggregates of fine-grained bytownite $\left(\mathrm{An}_{85}\right)$ and coarsegrained andesine $\left(\mathrm{An}_{45}\right)$ with some interstitial bytownite make up a highly inhomogeneous rock. Labradorite rock with inclusions of bytownite and biotite occurs in one locality in the southernmost body. Small clusters of hornblende and biotite give a mottled appearance to some massive outcrops of bytownite-andesine rock along the North Fork of the Clearwater River. A few andesine grains, some of them in feldspathized schist, show reversed zoning. Oscillatory zoning is. very rare.

Remnants of diopside-plagioclase gneiss and schlieren of biotite occur in the fine-grained andesine rock in the westernmost part of the southern body. In some outcrops plagioclase is bytownite $\left(\mathrm{An}_{85}\right)$ and epidote and hornblende occur as additional constituents. Andesinephlogopite rocks are interlayered. All these rocks contain some quartz and have layering similar to metasedimentary rocks.

Nord (1973) was able to map the middle body in detail because of new logging roads in areas of poor exposure. He found that the western part of this body consisted of layered anorthosite. The eastern part is massive and it merges with the southern extension of the northernmost body. In the western part, the layers of either pelitic or cal- careous affinity, and some thin quartzite layers persist parallel to the east-west trends of the surrounding country rocks.

In the middle body, along the West Fork of Cedar Creek (loc. 1409, Fig. 2) very light bluish gray layers, 10 to $30 \mathrm{~cm}$ thick, of andesinebytownite rock are separated by 1 - to 4 -cm-thick dark layers rich in hornblende or in biotite and muscovite. The plagioclase composes 70 to 100 percent of the light-colored layers and about 50 percent of the dark layers. In addition to biotite and muscovite, the dark layers contain, either kyanite, andalusite, and sillimanite, or cordierite, or hornblende, diopside, and zoisite or epidote. Layers and lenses of honblende-bytownite rock occur along the border zones.

The northernmost large mass consists of two types of massive anorthosite with foliated and layered border zones. Two, and locally three, kinds of plagioclase are common throughout the mass: these are andesine $\left(\mathrm{An}_{40-45}\right)$ with bytowniteanorthite $\left(\mathrm{An}_{80-98}\right)$ and labradorite $\left(\mathrm{An}_{59-62}\right)$ with anorthite and andesine. Labradorite rock occurs locally in the northernmost part and near Monumental Buttes (Fig. 2). Lath-shaped crystals in this rock show Carlsbad twinning, which is generally considered to indicate a liquid environment of crystallization. Nord (1973) determined that the inclusions in the labradorite laths are composed of anorthite rimmed by andesine, and he also found andesine along labradorite grain boundaries, but not in the anorthite groundmass between the labradorite crystals. Some inclusions have kyanite or corundum centers. Thin sections and microprobe analyses by Nord (1973) of samples collected mainly from the northernmost mass suggest that the andesine-bytownite (anorthite) and labradorite-anorthite ratios vary considerably from outcrop to outcrop. This variability indicates inhomogeneity of the bulk composition of plagioclase in the massive anorthosite.

Plagioclase content in samples collected by Hietanen (1963) supports this result. Thin sections show that near Orphan Point (loc. 1745, 
Fig. 2) andesine-labradorite $\left(\mathrm{An}_{50-53}\right)$ makes up 85 percent of the anorthosite and bytownite 15 percent. Along Rocky Run (loc. 1799) these percentages are 50 and 40 , respectively. A sample collected near the northern border at Lund Creek (loc. 1814, Fig. 2) has 90 percent labradorite and 7 percent bytownite-anorthite; near the border at Rocky Run (loc. 1696, Fig. 2), these percentages are 75 and 25 percent, respectively. In the small lenses in the surrounding schist, plagioclase is either bytownite-anorthite or andesine, or there are alternating thin layers of these two plagioclases. Hornblende and garnet, or aluminum silicates and micas occur as minor constituents.

The dark constituents in most of the massive anorthosite come to less than 3 percent. Locally, however, hornblende and chlorite occur in clusters and make as much as 20 percent of the rock. Epidote, ilmenite rimmed by sphene, kyanite, zoisite, and corundum occur as accessory minerals.

Fine-grained layered bytownite-anorthite rocks containing either hornblende, or garnet and quartz, or grossularite and diopside, or aluminum silicates and micas are common along the contact zones of all anorthosite. These rocks most likely are remnants of the calcic plagioclaserich parent rocks, calc-silicate rocks, and interbedded pelitic rocks that were transformed into two-plagioclase anorthosite by the partial replacement of calcic plagioclase by andesine.

The thin layers and lenses of anorthosite in the aluminum silicate-bearing garnet-mica schist below the two northern bodies (Fig. 2) consist of foliated one- or two-plagioclase rock. Andesine $\left(\mathrm{An}_{38-45}\right)$ usually occurs as large grains and bytownite-anorthite as fine-grained layers that also contain either quartz and grossularite or diopside and hornblende. Zoisite, chlorite, ilmenite, and sphene are the minor constituents. These lenses are mineralogically similar to the foliated hornblende anorthosite in the southern extension of the northernmost large body. The andesine is younger than the calcic plagioclase and occurs also in the schist as individual large grains, small masses, and veinlets. Nord (1973) reported graphite along with garnet, apatite, chlorite, quartz, diopside, and zoisite as minor constituents of hornblende-bearing anorthite $\left(\mathrm{An}_{85-94}\right)$ layers that were changed to twoplagioclase anorthosite by the partial replacement of calcic plagioclase by andesine.

In much of the two-plagioclase anorthosite the textures resemble typical replacement textures. The younger andesine $\left(\mathrm{An}_{40-45}\right)$ occurs as large, round-to-oval grains embedded in a fine-grained groundmass that consists of calcic plagioclase $\left(\mathrm{An}_{80-97}\right)$ similar to that in the bytownite-anorthite layers and lenses along the contacts and in the surrounding schist. The irregularly shaped bytownite inclusions in the andesine megacrysts and the groundmass next to them have recrystallized during the replacement to obtain crystallographic continuity but still showing ghost-like, earlier fine-grained texture. Extinction contrast of the inclusions and the host andesine shows the rotation of indicatrix with composition.

Juras (1974) paid particular attention to the textures of secondary andesine (»young anorthosite segregations») that had crystallized late along the fractures, shear planes, and faults in coarse-grained anorthosite. He found tiny vugs $(0.1-0.4 \mathrm{~mm}$ long) along these late structural planes, along shears, and along some grain boundaries in the labradorite. Three to four tiny anhedral-to-subhedral and euhedrally zoned crystals of andesine $\left(\mathrm{An}_{40-50}\right)$ to oligoclase $\left(\mathrm{An}_{20-30}\right)$ fill each of the vugs. Juras did not find these igneous textures to occur in common bimodal anorthosite with andesine crystalloblasts.

These textures can scarcely be considered to indicate an igneous origin for the Boehls Butte anorthosite, since euhedral and zoned andesine also occurs in the feldspathized cordieritesillimanite gneiss. For example, in the northwestern extension of the southern anorthosite body (loc. 922, Fig. 2), most andesine grains are anhedral to subhedral and are larger than the quartz 
and cordierite grains that occur between the large andesine grains and - together with sillimanite, biotite, muscovite, chlorite, and tourmaline form brown clusters in the white anorthosite. In this rock some plagioclase $\left(\mathrm{An}_{25-30}\right)$ crystals, bordered mainly by quartz, are zoned and euhedral or show euhedral zoning on one side of the center, which has a mottled extinction. The shear planes described by Juras (1974) may have served as avenues for invading solutions carrying sodium that transformed part of the calcic plagioclase to andesine.

\section{Origin of the anorthosite}

Possible igneous, metasedimentary and metasomatic origin for the anorthosite, as well as possible combinations of these, have been discussed (Hietanen 1963, p. 65-73). Trimodal labradorite laths with Carlsbad twinning (an igneous feature) occur locally in the northern part of the northernmost anorthosite body, but most of the massive anorthosite in this as well as in the middle body is massive bimodal anorthosite with large andesine megacrysts embedded in a fine-grained bytownite groundmass; it resembles the plagioclase layers in the layered anorthosite. Magmatic origin for this rock is questionable unless it can be shown either that in certain physico-chemical conditions, andesine and calcic plagioclase will crystallize as separate grains or that the exsolution of labradorite would yield a mixture of andesine and bytownite or anorthite. Moreover, the layering and remnants of older metasedimentary rocks, as well as their mineralogy, such as the occurrence of abundant aluminum silicates (kyanite, andalusite, and sillimanite), cordierite, biotite, muscovite, and chlorite in thin persistent layers, make an igneous origin of the layered bimodal anorthosite unlikely.

On the other hand, the metamorphism of alternating layers of calcareous shale and aluminum-rich shale and a short-distance migration of elements between these layers would pro- duce a layered calcic plagioclase rock which is the most likely parent rock for the layered twoplagioclase anorthosite. Potassium-poor magmas related to the early phase of the Idaho batholith could have been a source of sodium necessary for the partial replacement of calcic plagioclase by andesine. Carlsbad twins, which are considered as evidence for igneous origin, usually form in a liquid environment, but their presence does not indicate how the liquid was formed. Considering all the features typical of the metasedimentary rocks that occur in the two southern bodies, in the border zones of the northern body, and in the small anorthosite lenses, it is possible that the metamorphic parent rock was partially melted in places to allow the crystallization of labradorite laths with Carlsbad twinning, with the anorthite, kyanite, and corundum remaining in the labradorite as refractory inclusions.

If a magmatic origin and exsolution are assumed for the trimodal labradorite anorthosite, then two separate modes of origin (igneous and metamorphic) would have to be assumed for the massive and the layered andesine-bytownite anorthosite; that is not a likely situation in such a small area. A common origin for all anorthosite in this area is supported by the fact that all three large bodies have similar strontium isotope ratios. The average of six determinations of $\mathrm{Sr}^{87} / \mathrm{Sr}^{86}$ made by Stanley A. Heath (written commun. 1966) is $0.7046 \pm 0.0005$; for two border zone rocks with a high anorthite content it is 0.7061 , thus higher. Moreover, not all of the andesine grains contain bytownite-anorthite inclusions; some (the medium-size clear grains) are free of inclusions, and thus could not have been exsolved from the labradorite. These grains resulted from a secondary development of andesine similar to that in the feldspathized schist. The one- to two-plagioclase anorthosite containing thin layers and laminae of metamorphic minerals such as aluminum silicates (kyanite, andalusite, and sillimanite) cannot be igneous, but the melting of this rock could produce labradorite anorthosite with refractory 
inclusions of anorthite, kyanite, and corundum. The metamorphic-metasomatic origin with local melting was therefore preferred by Hietanen (1963) and by Nord (1973 and written commun.,

\section{References}

Althaus, E., 1967. The triple point andalusite-sillimanitekyanite. Contrib. Miner. Petrol. 16, 29-44.

Hietanen, Anna, 1956. Kyanite, andalusite, and sillimanite in the schist in Boehls Butte quadrangle, Idaho. Amer. Mineral. 41, 1-27.

-, 1963. Anorthosite and associated rocks in the Boehls Butte quadrangle and vicinity, Idaho. U.S. Geol. Surv. Prof. Pap. 344-B, 78 p.

—, 1969a. Metamorphic environment of anorthosite in the Boehls Butte area, Idaho, in Isachsen, Y. W., ed., The origin of anorthosite and related rocks. New York State Museum and Science Service Memoir 18, 371-386.

-, 1969b. Distribution of $\mathrm{Fe}$ and $\mathrm{Mg}$ between garnet, staurolite, and biotite in aluminum-rich schist in various metamorphic zones north of the Idaho batholith. Amer. Journ. Sci. 267, 422-456.

,- 1984 . Geology along the northwest border zone of the Idaho batholith. U.S. Geol. Surv. Bull. 1608, 17 p.
1976), and is supported by the present study and by the fact that no ilmenitic iron ores - commonly associated with igneous anorthosites - occur in the Boehls Butte area.

Juras, D. S., 1974. The petrofabric analysis and plagioclase petrography of the Boehls Butte anorthosite: Unpubl. Ph.D. thesis, Univ. Idaho.

Newton, R. C., 1966. Kyanite-sillimanite equilibrium at $750^{\circ} \mathrm{C}$. Science $151,1222-1225$.

Nord, G. L., Jr., 1973. The origin of the Boehl's Butte anorthosite and related rocks, Shoshone county, Idaho. Unpublished Ph.D. thesis, Univ. Calif., Berkeley.

Richardson, S. W., Gilbert, M. C., and Bell, P. M., 1969. Experimental determination of kyanite-andalusite and andalusite-sillimanite equilibria: the aluminum silicate triple point. Amer. Journ. Sci. 267, 259-272.

Schreyer, W., and Seifert, F., 1969. Compatibility relations of the aluminum silicates in the systems $\mathrm{MgO}-$ $\mathrm{Al}_{2} \mathrm{O}_{3}-\mathrm{SiO}_{2}-\mathrm{H}_{2} \mathrm{O}$ and $\mathrm{K}_{2} \mathrm{O}-\mathrm{MgO}-\mathrm{Al}_{2} \mathrm{O}_{3}-\mathrm{SiO}_{2}-$ $\mathrm{H}_{2}$ O. Amer Journ. Sci. 267, 371-388.

Seifert, F., 1973. Stability of the asemblage cordieritecorundum in the system $\mathrm{MgO}-\mathrm{Al}_{2} \mathrm{O}_{3}-\mathrm{SiO}_{2}-\mathrm{H}_{2} \mathrm{O}$. Contrib. Mineral. Petrol. 41, 171-178. 